\title{
ORGANIZATIONAL AND ECONOMIC MECHANISM OF A BUSINESS SECURITY AS A GUARANTEE OF ITS SUSTAINABLE DEVELOPMENT
}

\author{
Volodymyr Tkachenko, Iryna Tkachenko, Polina Puzyrova, and Andriy Klochko
}

\begin{abstract}
In the process of the writing of this article, it was established that the organizational and economic mechanism of a business security ensuring involves the use of various techniques, methods, and tools. Their combination is necessary to ensure a reliable security system and stable sustainable development of a business activity as a whole. It has been established that enterprises of different sizes, types, volumes of activity possess unequal organizational and financial capabilities. In addition, various is the level of risk under which business entities are engaged. However, the conclusion is definite that the implementation of the organizational and economic mechanism for the enterprise security ensuring is vital in financial and economic aspects and can be organized in different business areas in different ways. It is proved that the security mechanism action from the point of view of financial and economic aspect implies enterprise adaptation to innovations under the following conditions: the innovations are to be maximally ready for implementation; the motivation to implement them is the need to protect the enterprise interests; the probability of obtaining a positive result in the implementation of innovations should be high. It has been established that significant factors in the process of increasing the level of a business security are the financial and economic measures, which aim to cover losses and to eliminate the causes of their occurrence, to recover (preserve) the liquidity and solvency, to reduce the amount of debt, to improve the working capital structure, etc. It is proved that further research in the field of planning and implementation of tactical measures for ensuring the financial and economic security of business is needed. It is aimed at the assessment and analysis of the level of a business security and its dynamics, which will allow to determine the effectiveness of the implemented measures; an assessment of the efficiency of utilization of the enterprise financial potential, which is the main basis for the implementation of measures to ensure the organizational and economic mechanism of a business security. Since the implementation of organizational and economic tools into the security field often requires the allocation of significant financial resources and opportunities (financial potential), the substantiation of scientific recommendations for assessing costeffectiveness become significant. It was found that the organizational and economic mechanism of a business security ensuring would effectively use corporate resources, create preconditions for achieving business targets, timely identify and optimize all possible hazards, threats, and risks of the enterprise activity in the conditions of acute competition and changing environment. It is recommended to propose the following measures to enhance business security: development and implementation of security system (structure) in business processes of the enterprise activity; improvement and optimization of the existing enterprise security service; business security outsourcing services; services of the enterprise personnel security; provision of services to provide economic and internal
\end{abstract}


security of the enterprise; providing necessary data and information for the business functioning security insurances; checking (auditing) of existing security services of enterprises for their effective work and reliability; services for the enterprise security employees training (advanced training); personnel selection of professionally trained staff for the enterprise security service.

Keywords: economic security, enterprise, efficiency, business security, development, management, organizational and economic mechanism.

JEL Classification: M00, 010, L50

\section{Authors:}

\section{Volodymyr Tkachenko}

The London Academy of Science and Business, 3rd Floor, 120 Baker Street, London, England, W1U 6TU

E-mail: vladymyr8888@gmail.com

https://orcid.org/0000-0003-2114-7194

\section{Iryna Tkachenko}

Academy of the State Penitentiary Service, 34, Honcha Street, Chernihiv, Ukraine, 14000

E-mail: irinat116@gmail.com

https://orcid.org/0000-0001-9068-1054

\section{Polina Puzyrova}

Kyiv National University of Technologies and Design (KNUTD), 2, Nemyrovycha-Danchenka Street, Kyiv, Ukraine, 01011

E-mail: komaretskaya@bigmir.net

https://orcid.org/0000-0003-0839-8730

\section{Andriy Klochko}

National Academy for Public Administration under the President of Ukraine, 20, Ezhena Pottier Street, Kyiv, Ukraine, 03057

E-mail: klochko.andriy@gmail.com

https://orcid.org/0000-0002-1691-2333

Citation: Tkachenko, V., Tkachenko, I., Puzyrova, P., \& Klochko, A. (2019). Organizational and economic mechanism of a business security as a guarantee of its sustainable development. Virtual Economics, 2(4), 71-85. https://doi.org/10.34021/ve.2019.02.04(4) 


\section{Introduction}

Economic security of a business is a complex concept that connects not so much with the internal state of the business itself, as with the external environment influence, the subjects that it interacts with. Thereby, it is more likely to state that business economic security creates coherence, balance of interests of the enterprise and the interests of environmental subjects (Andrushkiv \& Maliuta, 2016; Demirgüç-Kunt et al., 2017).

From this point of view, economic security of a business can be considered as the practical implementation of the theory provisions of resource interdependence, according to which the enterprise should take into account not only its own interests, but also the interests of the partners, whose activity range can be very broad (Bertay et al., 2017). Exactly, from this perspective of coherence of the enterprise interests and interacting subjects of the external environment, it is supposed to explore the concept of business economic security.

\section{Literature review}

The main issues related to modern aspects of economic security, management of economic security, its components and mechanism were covered in the following works of Ukrainian scientists: (Andrushkiv \& Maliuta, 2016; Bilomistna et al., 2014) - theoretical and methodological provisions of organization and economic security ensuring at the enterprise were considered. The organization of anti-raiding experience measures in the conditions of both Ukrainian and CIS countries enterprises and business activity is generalized; the origin and nature of raiding are presented; the classification that discloses methods and technology of property seizure with the use of experience, economic and legal means of protection against the raider seizure of the enterprise are proposed.

Next group of scientists (Bondarenko, 2014; Boiko et al., 2019; Dzwigol et al., 2019a; 2019c; Kwilinski, 2018; 2019a; 2019b; 2019c; Savchenko et al., 2019) examined the economic security of an innovative enterprise, where they considered the essence and the basic principles of the economic security development and functioning system of innovative enterprises, the process and mechanism of this system managing; revealed the essence, basic functions and significance of economic security system management in the activity of the modern innovative enterprise. Scientists (lershova et al., 2019) have revealed the theoretical and methodological foundations of enterprise economic security management, its place and role in the enterprise management system.

For effective functioning and development of enterprises, the authors developed and offered methods of diagnostics of threats and complex estimation of the level of economic safety of the enterprises, organizational support of economic safety management of the enterprises. The authors have developed, and proposed the methods of threat diagnostics and the comprehensive evaluation of the level of economic security of the enterprises, of the economic security organizational management of the enterprises. The paper (Momot, 
2015; Dzwigol et al., 2019b) presents theoretical and methodological approaches of economic security ensuring at national and regional levels, development and practical implementation of tools, assessing and monitoring the European standards level of financial and economic security, systematic analysis of risks corruption to ensure effective interaction of state anti-corruption issues. The authors improved the information and analytical support processes of strategic analytics and audit in the system of financial and economic security of the state, region, business entities in the conditions of the aggravation of threats and challenges of a new type in the field of national and international security and absorption of European integration processes, taking into account the importance of the Ukrainian national security policy adaptation within the framework of the European civilization model.

In foreign countries, the issues of economic security were studied in the works of E. Azara, L. Brown, B. Brody, 3. Brzezinski, R. Jackson, D. Kauffman, L. Kozhenovski, W. Lippman, G. Morgenthau, G. Foster and others.

\section{Methods}

To write the article, the following general scientific and special methods of scientific research were used: concretization and abstraction - for consensual determination of economic security; grouping - for systematization approaches to management of the organizational and economic mechanism of economic security; logical generalization and comparison - to assess the mechanism of management of economic security of the enterprise; analysis and synthesis - with the study of cause-effect relations between the components of economic security, and the interests of the enterprise; formalization and systematization - in determining the conceptual principles of management of the financial component of the economic security of a business.

\section{Results and Discussion}

Economic security of a business can be considered as a measure of coherence in time and space of economic interests of the enterprise with the entity's interests connected with the external environment acting outside the enterprise (Buse \& Wu, 2007; Cyert \& March, 1992).

Proposed understanding of business economic security allows to assert that the enterprise activity itself is economically secured if its economic interests are cohered with the interests of the external environment consumers, suppliers, competitors, investors, the state and society as a whole (Lien, 2017). The compacted systematization of external environmental entities, which interact with the enterprise, can be represented by the following directions (Fig. 1) (Andrushkiv \& Maliuta, 2016). In the study of the concept of "economic security of enterprises" (Tkachenko et al., 2019a; 2019b; 2019c; 2019d), it follows that there is the study of the basic concept of "economic security" with the notion of "interests of the enterprise", as well as naturally related to it the criterion of company's interests observance (Sobolev \& Soboleva, 2015). 


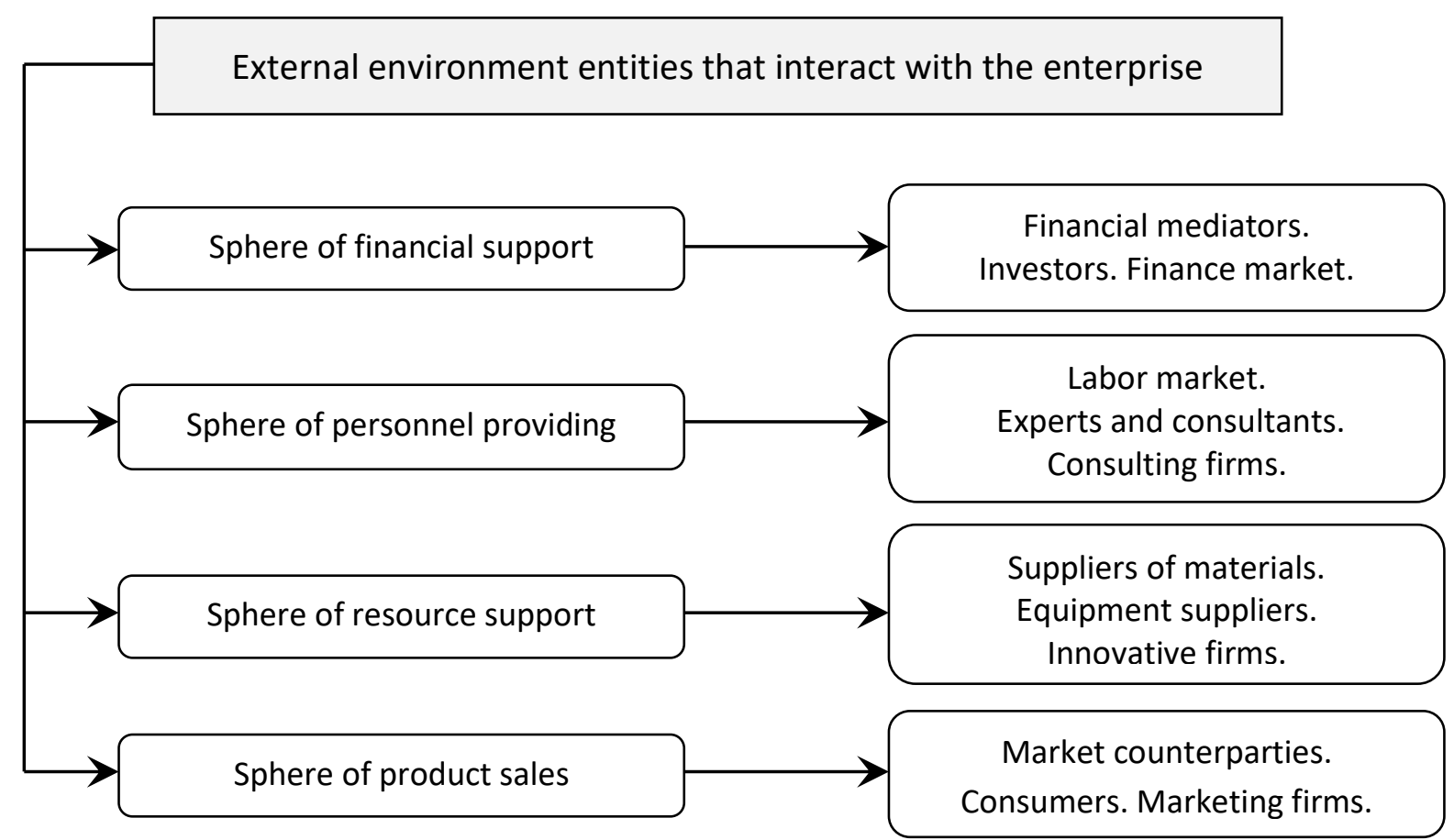

Figure 1. The subjects of external environment interaction with the enterprise Source: (Sobolev \& Soboleva, 2015).

The interpretation of the word "interest" meaning allows us to conclude that this is the benefit, the profit, the income, and the result of studying of enterprise interests as its interaction with the external environment subjects, which actively fulfill its activity, forcibly or by enterprise choice, which results in providing profit (Andrushkiv \& Maliuta, 2016; Drucker, 1986). The interests of enterprises are inalienable from their entities, as the interests of the enterprise are personalized category (Dzhafarova et al., 2019). In this regard, it is necessary to allocate the enterprise interests. Personification of the enterprise entities interests is conditioned by such factors as the form of ownership on the means of production and, accordingly, organizational and legal form of enterprise activity, as well as the kind of interests. According to these factors, the pyramid of enterprise interests can be presented in such a way which is shown in Fig. 2 (Andrushkiv \& Maliuta, 2016; Johnson \& Scholes, 1993). 


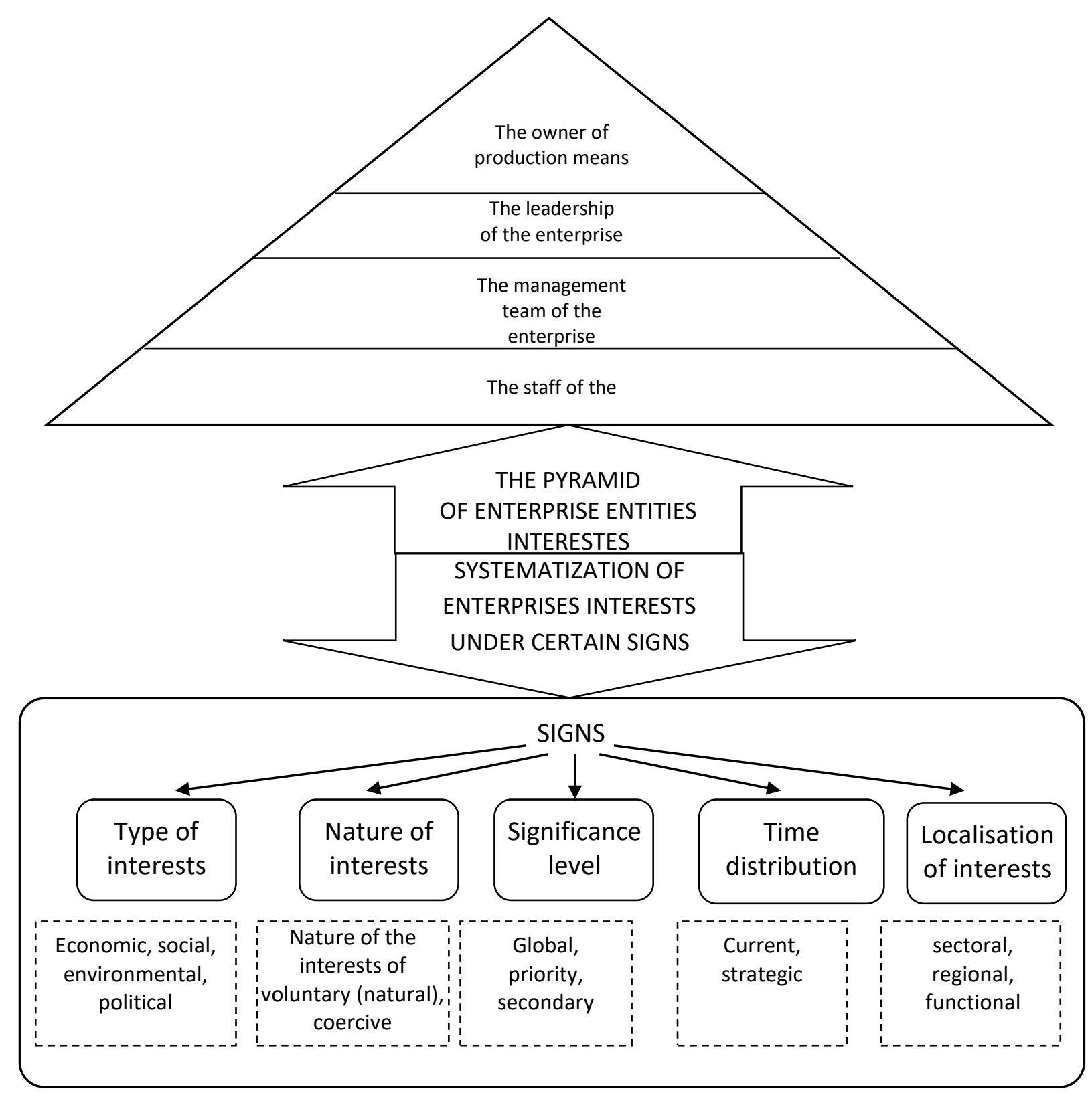

Figure 2. Pyramid of interests according to the signs of systematization of enterprise interests

Source: (Andrushkiv \& Maliuta, 2016).

The control entity forms the system of interests of the company and, consequently, influences its economic security. Real control over of the enterprise activities may be carried out by the third party entities, for example, creditors (Hlynska, 2016; Gorton et al., 2010). The coincidence or divergence of interests of the controlling entity and the enterprise is important (Dźwigoł \& Wolniak, 2018; Mavrotas \& Vinogradov, 2007). If their interests coincide, if the controlling entity has investments significant in terms of the structure of the 
enterprise asset, for example, in the form of credits, if the controlling entity is interested in the sustainable and dynamic development of the enterprise, then the presence of the controlling entity cannot be considered as a negative factor in the enterprise development (Andrushkiv \& Maliuta, 2016; Gorton et al., 2010). Due to the large number of environmental entities with which the enterprise directly or indirectly interacts, the interests of the enterprise are very diverse, and each enterprise is characterized by its own totality of interests, in some ways related to each other, having a different status, and belonging to different entities. The interests of the enterprise do not remain constant and change over time, the diversity and mobility of the enterprise interests cause the need for their systematization by a number of signs and arrangements based on this systematization (Momot, 2015). Therefore, it is advisable to systematize the enterprise interests in accordance with certain signs (Fig. 2), (Andrushkiv \& Maliuta, 2016).

Based on the study, it is expedient to distinguish a number of principles on which the process of forming the system of enterprise interests and ensuring its economic security is built (Fig.3), (Andrushkiv \& Maliuta, 2016).

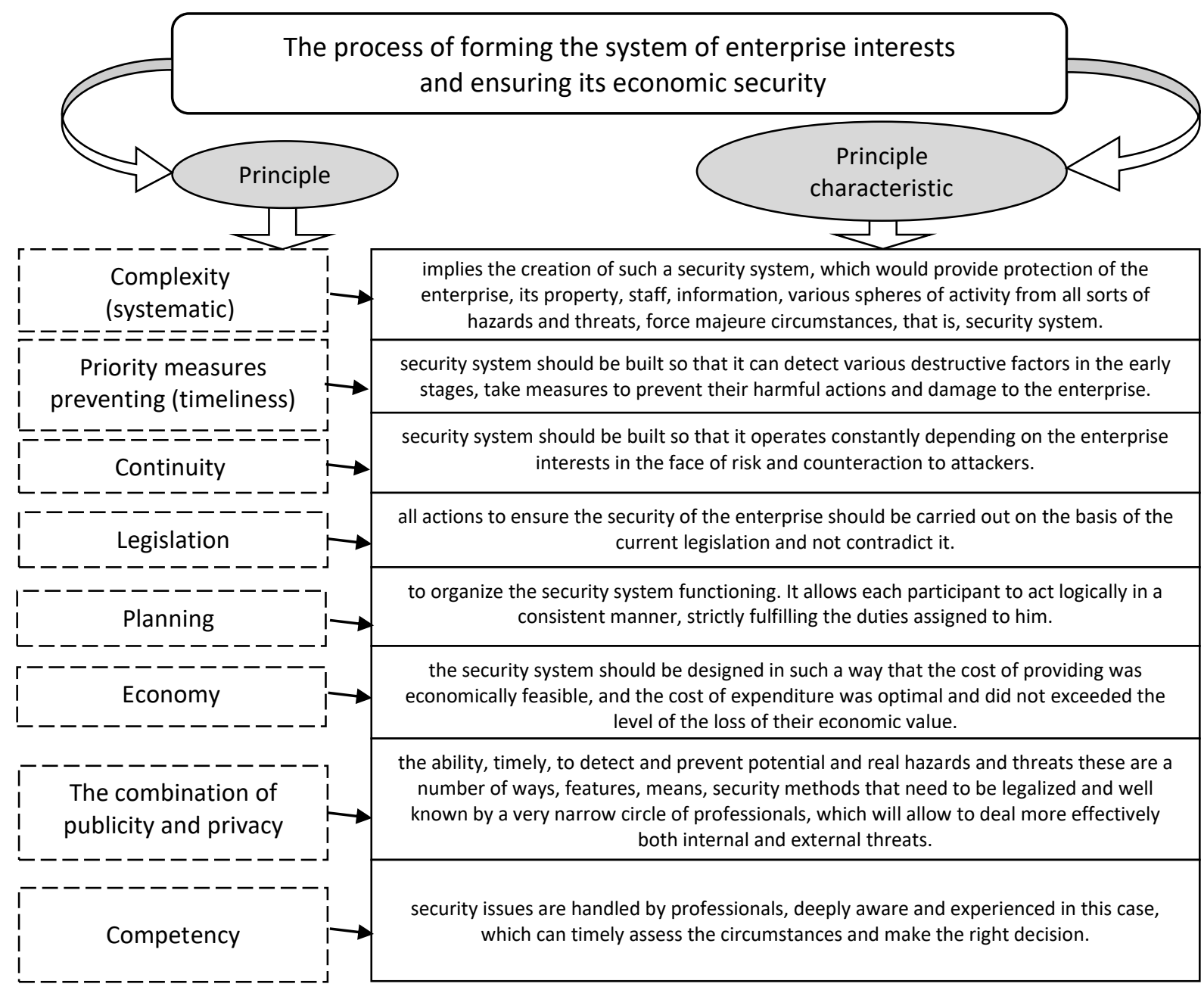


Figure 3. Principles on which the process of forming the system of the enterprise interests and ensuring its economic security is built

Source: (Andrushkiv \& Maliuta, 2016).

Organizational and economic mechanism of business security (Green et al., 1991; HayesRoth, 1991) (objects, subjects, principles, security functions, enterprise security policy, strategies) is a system of opinions, measures, decisions, actions in the field of security that creates favourable conditions for business targets achievement, that is, the security policy allows the company to perform the production program to produce competitive products (goods, services, works), increase production efficiency, increase ownership, get profits, etc. (Andrushkiv \& Maliuta, 2016; Korchevska \& Kokoreva, 2016). The security strategy is a set of the most significant solutions aimed at ensuring the programmatic level of security of the enterprise. The security strategies are different in their content. In practice, there are three types of enterprise security strategies. They are shown in Fig. 4:

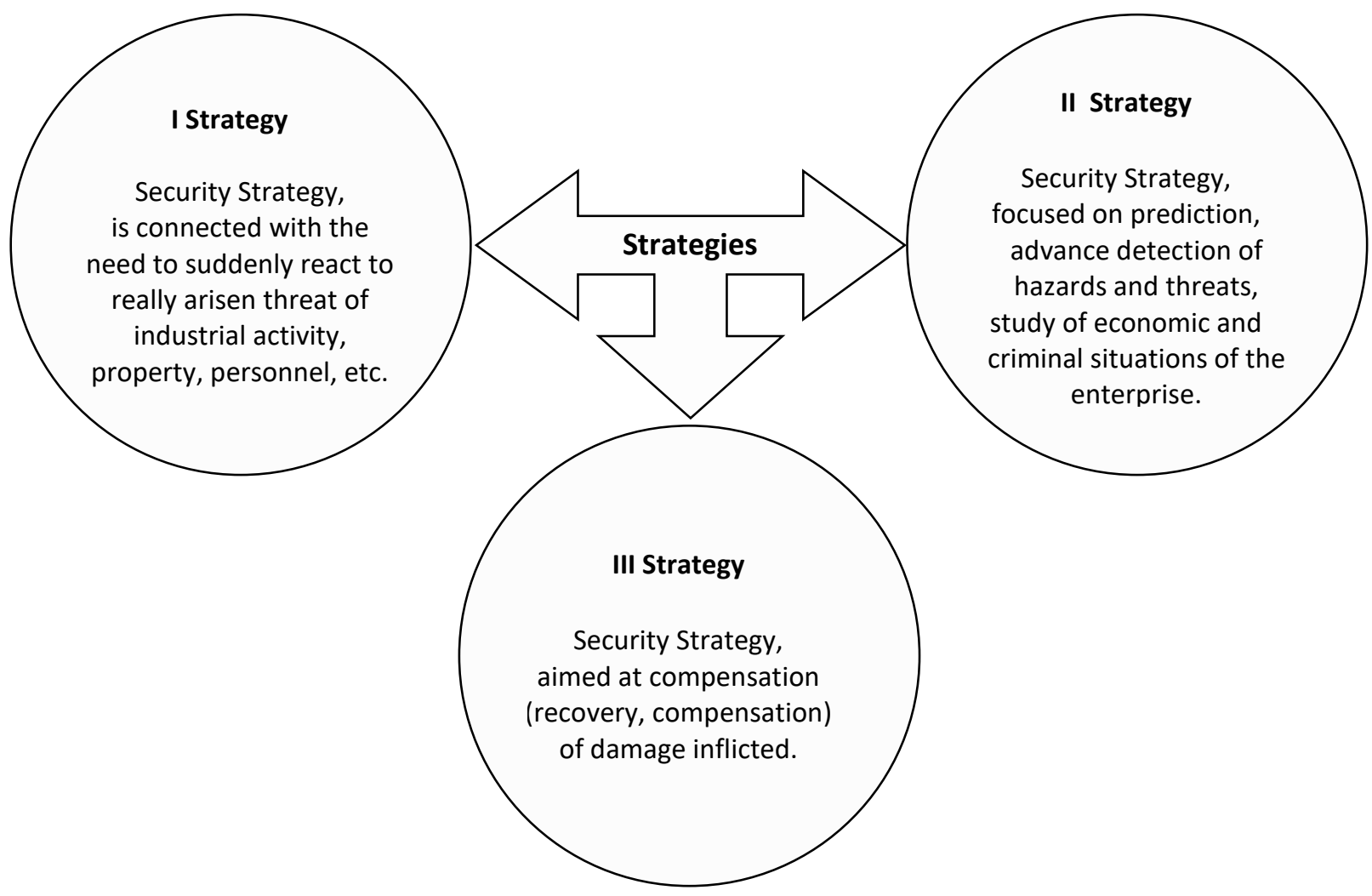

Figure 4. Enterprise security strategies

Source: (Korchevska \& Kokoreva, 2016).

It should also be noted that the security system of the business is delimited by many interconnected elements that ensure the security of the enterprise and the targets of its business achievement (Neanidis, 2019; Osberg, 1997). The elements of such system are the object and security entity, security management mechanism, as well as strategic actions for security management. The object of security is the fact that the security efforts are directed. 
The objects include: different activities of the enterprise (production, commerce, delivery, management, etc.); enterprise property and resources (financial, material, and technical, information, intellectual, etc.); staff of the firm, its managers, shareholders, various structural subdivisions, services, partners, employees possessing information which is a commercial secret, etc. (Liashenko, 2011; Mishchenko et al., 2019).

The enterprise security entities are those persons, subdivisions, services, bodies, departments, institutions which are directly engaged in business security ensuring. As the enterprise security activity is multifaceted, this task cannot be accomplished with the help of one or two bodies. As a rule, many entities are classified as security entities, which can be classified by different signs (Andrushkiv \& Maliuta, 2016; Nebava, 2017; Nikitina et al., 2019):

a) depending on their affiliation: the entities engaged in these activities

directly at the enterprise, as well as external bodies and organizations;

b) depending on the subject of direct engagement: special entities and other staff of the enterprise;

c) depending on the action (impact) on the security entity: the entities of direct and indirect purpose;

d) depending on legitimacy: official bodies and criminal structures ("roofs");

e) depending on the level of subordination: to public authorities and non-state bodies.

Therefore, all security entities can be identified in two groups (Kadan et al., 2016):

- the first group includes those entities that enter the structure of the business itself and solve the tasks for ensuring its safety (special entities, as well as the rest of the company staff, who also care about the safety of their enterprise);

- the second group includes those entities that are outside the enterprise and are not subordinate to its management.

First of all these are the state bodies that create the conditions for ensuring the security of the enterprise:

- legislative bodies - adopt laws that create the legal basis for security activities at the level of the state, region, enterprises and individuals;

- executive authorities - implement policies, detail security mechanisms;

- judicial authorities - ensure compliance with the legal rights of the enterprise and its employees;

- state institutions - carry out border protection, customs, currency export, tax control, etc.;

- law enforcement agencies - fight offenses and crimes;

- system of scientific institutions - implements the tasks of scientific elaboration of problems of security and training in that field (Krainer, 2017; Collins \& Gallagher, 2016).

With the beginning of the market reforms, both state and non-state organizations, agencies, institutions began to form. These are various private security and detective organizations, 
analytical institutions, information services, educational, scientific, and consulting organizations, etc. They usually provide security services for an appropriate fee, provide information protection, trade secrets, collect information about competitors, unreliable partners, etc. (Hammoudeh \& McAleer, 2013).

\section{Conclusions}

Thus, in the process of the writing of this article, we have found that the organizational and economic mechanism for business security ensuring involves the use of techniques, methods, and tools, the combination of which is necessary to ensure a reliable security system and sustainable development of enterprise activity in general (Tkachenko et al., 2019b). It is clear that enterprises of different sizes, types, volumes of activity possess unequal organizational and financial possibilities. In addition, the level of risk to which business entities operate is various. However, the definite conclusion is that the implementation of an organizational and economic mechanism to ensure the security of the enterprise in financial and economic aspects is vital and can be organized in different business areas in different ways (Silva et al., 2017).

The effect of the security mechanism regarding the financial and economic aspect implies the adaptation of the enterprise to innovations, provided by the following conditions: innovations should be maximally ready for implementation; motivated to implement them, it is necessary to protect the interests of the enterprise; probability of obtaining a positive result in the implementation of innovations should be high (Allen \& Wood, 2006; Williamson, 1975). A significant place in the process of increasing the level of a business security is occupied by financial and economic measures aimed at covering losses and eliminating the causes of their occurrence, restoration (preservation) of liquidity and solvency, reduction of the amount of debt, improvement of the current assets structure etc.

The activity of forming a reliable system of financial and economic security at the enterprise may involve the application of such economic measures:

- optimization of direct and indirect expenses of activity;

- implementation of budget financing and funds centralization;

- saving resources; reduction of receivable accounts;

- improvement of the system of mutual settlements;

- improvement of the system of labor stimulation;

- price improvement;

- financing of activity and development of enterprise sources optimization.

The prospect of further research is that without a proper level of a business security it is not possible to achieve a stable profitable business activity, within the informational measures is the important group of measures necessary for the development of the enterprise financial and economic security system: informing employees on the purpose, tasks, program, opportunities and consequences of the economic security management of a business activity policy; protection of important information and enterprise commercial secrets; informing 
about changes of plans, tasks to ensure business security (Huang \& Wang, 2013; Sobolev \& Soboleva, 2015; Vishnevsky \& Kwilinski, 2019a; 2019b; Lachno et al., 2018; Pająk et al., 2016).

Further research is needed in the field of planning and implementation of tactical measures to ensure the financial and economic security of a business, which is aimed at: assessment, and analysis of a business security level and its dynamics, which will allow determining efficiency of implemented activities; assessment of efficiency of using the financial potential of the enterprise, which is the main basis when implementing measures to ensure the organizational and economic mechanism of a business security. Since the implementation of organizational and economic means in the field of security often requires the allocation of significant financial resources and opportunities (financial potential), the substantiation of scientific recommendations for cost - effectiveness assessment is of significant importance (Chen et al., 2019). Thus, it can be concluded that the organizational and economic mechanism of a business security ensuring will effectively use corporate resources, create preconditions for business targets achievement, timely identify and optimize all possible hazards, threats, and risks of enterprise activity in conditions of fierce competition and changing environment. Also, to enhance business security, it is possible to propose the following: development and implementation of a system (structure) of enterprise business activity security processes; improvement and optimization of the existing security service at the enterprise; business security outsourcing services; services of the enterprise staff security; provision of the enterprise economic and internal security services; information providing the necessary data for the safe functioning of the business; checking (auditing) of existing security services of enterprises for their effective work and reliability; services of the enterprise security staff training (advanced training); the enterprise security professionally trained staff selection service.

\section{References}

Allen, W.A., \& Wood, G. (2006). Defining and achieving financial stability. Journal of Financial Stability, 2(2), 152-172. https://doi.org/10.1016/j.jfs.2005.10.001

Andrushkiv, B.M., \& Maliuta, L.Ya. (2016). Ekonomichna ta mainova bezpeka biznesu: navchalnyi posibnyk [Economic and property security of business: a textbook]. Ternopil: FOP Palianytsia V.A. [in Ukrainian].

Bertay, A.C., Gong, D., Wagner, W. (2017). Securitization and economic activity: The credit composition channel. Journal of Financial Stability, 28, 225-239. https://doi.org/10.1016/j.jfs.2016.01.010

Bilomistna, I. I., Bilomistniy, O. M., Kramska, M. (2014). The system to ensure the financial security of businesses. Financial and Credit Activity: Problems of Theory and Practice, 2(17), 106-114. https://doi.org/10.18371/fcaptp.v2i17.37326

Boiko, V., Kwilinski, A., Misiuk, M., \& Boiko, L. (2019). Competitive advantages of wholesale markets of agricultural products as a type of entrepreneurial activity: the experience of Ukraine and Poland. Economic Annals-XXI, 175(1-2), 68-72. https://doi.org/10.21003/ea.V175-12 
Bondarenko, O. O. (2014). Finansovo-ekonomichna bezpeka pidpryiemstva: teoretychnyi ta praktychnyi aspekty [Financial and economic security of the enterprise: theoretical and practical aspects]. Efektyvna ekonomika - Efficient economy, 10. Retrieved from http://www.economy.nayka.com.ua/?op=1\&z=3580 [in Ukrainian].

Buse, D.P., \& Wu, Q.H. (2007). IP Network-based Multi-agent Systems for Industrial Automation. Information Management, Condition Monitoring and Control of Power Systems. London: Springer. https://doi.org/10.1007/978-1-84628-647-6

Chen, Y.-L., Chuang, Y.-W., Huang, H.-G., \& Shih, J.-Y. (2019). The value of implementing enterprise risk management: Evidence from Taiwan's financial industry. The North American Journal of Economics and Finance, 100926. https://doi.org/10.1016/j.najef.2019.02.004

Collins, S., \& Gallagher, E. (2016). Assessing the credit risk of money market funds during the eurozone crisis. Journal of Financial Stability, 25, 150-165. https://doi.org/10.1016/j.jfs.2015.12.001

Cyert, R. M., \& March, J.G. (1992). A Behavioral Theory of the Firm, 2nd Edition. Oxford: Blackwell.

Demirgüç-Kunt, A., Horváth, B.L., \& Huizinga, H. (2017). How does long-term finance affect economic volatility? Journal of Financial Stability, 33, 41-59. https://doi.org/10.1016/j.jfs.2017.10.005

Drucker, P.F. (1986). Management: Tasks, Responsibilities, Practices. New York: Truman Talley Books.

Dzhafarova, M. V., Shevchuk, T. A., Kalinovskaya, M.V., \& Stashchak, A.Yu. (2019). Ekonomichna bezpeka ukrainy: ekonomiko-pravovyi aspekt [Economic security of Ukraine: economic and legal aspect]. Financial and Credit Activity: Problems of Theory and Practice, 3(30), 78-84. https://doi.org/10.18371/fcaptp.v3i30.179511 [in Ukrainian].

Dźwigoł, H., \& Wolniak, R. (2018). Controlling w procesie zarządzania chemicznym przedsiębiorstwem produkcyjnym [Controlling in the management process of a chemical industry production company]. Przemysl Chemiczny, 97(7), 1114-1116. https://doi.org/10.15199/62.2018.7.15 [in Polish].

Dzwigol, H., Aleinikova, O., Umanska, Y., Shmygol, N., \& Pushak, Y. (2019a). An Entrepreneurship Model for Assessing the Investment Attractiveness of Regions. Journal of Entrepreneurship Education, 22, (SI1), 1-7. Retrieved from https://www.abacademies.org/articles/Anentrepreneurship-model-for-assessing-the-investment-1528-2651-22-S1-339.pdf

Dzwigoł, H., Dzwigoł-Barosz, M., Zhyvko, Z., Miskiewicz, R., \& Pushak, H. (2019b). Evaluation of the energy security as a component of national security of the country. Journal of Security and Sustainability Issues, 8(3), 307-317. http://doi.org/10.9770/jssi.2019.8.3(2)

Dźwigoł, H., Shcherbak, S., Semikina, M., Vinichenko, O., \& Vasiuta, V. (2019c). Formation of Strategic Change Management System at an Enterprise. Academy of Strategic Management Journal, 18(SI1), 1-8. Retrieved from https://www.abacademies.org/articles/Formation-of-strategicchange-management-system-at-enterprise-1939-6104-18-SI-1-454.pdf

Gorton, G., He, P., \& Huang, L. (2010). Security Price Informativeness with Delegated Traders. American Economic Journal: Microeconomics, 2(4), 137-70. https://doi.org/10.1257/mic.2.4.137

Green, M.R., Trieschmann, J.S., \& Gustavson, S.G. (1991). Risk \& Insurance, 8th Edition. Cincinnati: South-Western Pub. 
Hammoudeh, S., \& McAleer, M. (2013). Risk management and financial derivatives: An overview. The North American Journal of Economics and Finance, 25, 109-115. https://doi.org/10.1016/j.najef.2012.06.014

Hayes-Roth, B. (1991). An integrated architecture for intelligence agents. ACM SIGART Bulletin, 2(4), 79-81. https://doi.org/10.1145/122344.122359

Hlynska, A. (2016). Sutnist kreatyvnoho potentsialu orhanizatsii v konteksti zabezpechennia yii ekonomichnoi bezpeky [The essence of creative potential of organization in the context of providing its economic security]. Financial and Credit Activity: Problems of Theory and Practice, 1(20), 51-59. https://doi.org/10.18371/fcaptp.v1i20.73176 [in Ukrainian].

Huang, Y.S., \& Wang, Y. (2013). Asset price, risk transfer and economic activities: Firm-level evidence from China. The North American Journal of Economics and Finance, 26, 663-676. https://doi.org/10.1016/j.najef.2012.10.008

lershova, N.Yu., \& Tkachenko, M.O., Garkusha, V.O., Miroshnyk, O.Yu., \& Novak-Kalyayeva, L.M. (2019). Ekonomichna bezpeka pidpryiemstva: naukovo-praktychni aspekty oblikovoanalitychnoho zabezpechennia [Economic security of the enterprise: scientific and practical aspects of accounting and analytical support]. Financial and Credit Activity: Problems of Theory and Practice, 2(29), 142-149. https://doi.org/10.18371/fcaptp.v2i29.172365 [in Ukranian].

Johnson, G., \& Scholes, K. (1993). Exploring corporate strategy. New York: Prentice Hall.

Kadan, O., Liu, F., \& Liu, S. (2016). Generalized Systematic Risk. American Economic Journal: Microeconomics, 8(2), 86-127. https://doi.org/10.1257/mic.20140244

Korchevska, L., \& Kokoreva, O. V. (2016). Teoretychni aspekty synerhetychnoho upravlinnia ekonomichnoiu bezpekoiu pidpryiemstva [Theoretical aspects of synergetic management of economic security of enterprise]. Financial and Credit Activity: Problems of Theory and Practice, 1(20), 60-70. https://doi.org/10.18371/fcaptp.v1i20.73179 [in Ukrainian].

Krainer, R.E. (2017). Economic stability under alternative banking systems: Theory and policy. Journal of Financial Stability, 31, 107-118. https://doi.org/10.1016/j.jfs.2017.05.005

Kwilinski, A. (2019). Implementation of Blockchain Technology in Accounting Sphere. Academy of Accounting and Financial Studies Journal, 23(SI2), 1528-2635-23-SI-2-412: 1-6. Retrieved from https://www.abacademies.org/articles/Implementation-of-Blockchain-Technology-inAccounting-Sphere-1528-2635-23-SI-2-412.pdf

Kwilinski, A., Dalevska, N., Kravchenko, S., Hroznyi, I., Kovalenko, I. (2019a). Formation of the entrepreneurship model of e-business in the context of the introduction of information and communication technologies. Journal of Entrepreneurship Education, 22(SI1), 1528-2651-22-S1337: 1-7. Retrieved from https://www.abacademies.org/articles/Formation-of-theentrepreneurship-model-of-e-business-1528-2651-22-S1-337.pdf

Kwilinski, A., Ruzhytskyi, I., Patlachuk, V., Patlachuk, O., \& Kaminska, B. (2019b). Environmental Taxes as a Condition of Business Responsibility in the Conditions of Sustainable Development. Journal of Legal, Ethical and Regulatory Issues, 22(SI2) 1544-0044-22-SI-2-354: 1-6. Retrieved from https://www.abacademies.org/articles/Environmental-taxes-as-a-condition-of-businessresponsibility-in-the-conditions-of-sustainable-development-1544-0044-22-SI-2-354.pdf

Kwilinski, A., Volynets, R., Berdnik, I., Holovko, M., \& Berzin, P. (2019c). E-Commerce: Concept and Legal Regulation in Modern Economic Conditions. Journal of Legal, Ethical and Regulatory Issues, 
22(SI2), 1544-0044-22-SI-2-357: 1-6. Retrieved from https://www.abacademies.org/articles/ECommerce-concept-and-legal-regulation-in-modern-economic-conditions-1544-0044-22-SI-2357.pdf

Lien, D. (2017). Business Finance and Enterprise Management in the Era of Big Data: An introduction. The North American Journal of Economics and Finance, 39, 143-144. https://doi.org/10.1016/j.najef.2016.10.002

Lakhno, V., Malyukov, V., Bochulia, T., Hipters, Z., Kwilinski, A., \& Tomashevska, O. (2018). Model of managing of the procedure of mutual financial investing in information technologies and smart city systems. International Journal of Civil Engineering and Technology, 9(8), 1802-1812. Retrieved from http://www.iaeme.com/MasterAdmin/UploadFolder/IJCIET_09_08_181/IJCIET_09_08_181.pdf

Liashenko, O.M. (2011). Kontseptualizatsiia upravlinnia ekonomichnoiu bezpekoiu pidpryiemstva [Conceptualization of enterprise economic security management]. Luhansk, Ukraine: SNU im. V. Dalia [in Ukraine].

Mavrotas, G., \& Vinogradov, D. (2007). Financial sector structure and financial crisis burden. Journal of Financial Stability, 3(4), 295-323. https://doi.org/10.1016/j.jfs.2007.06.001

Mishchenko, V.A., Shevchenko, M.M., Sitak, I.L., Oryekhova, K.V, \& Yavorsky, S.V. (2019). Theoretical bases of providing the economic sustainability of the enterprise. Financial and Credit Activity: Problems of Theory and Practice, 3(30), 121-127. https://doi.org/10.18371/fcaptp.v3i30.179521

Momot, T. V. (2015). Finansovo-ekonomichna bezpeka: stratehichna analityka ta audytorskyi suprovid: monohrafiia [Financial and Economic Security: Strategic Analytics and Audit Support: A Monograph]. Kharkiv, Ukraine: KhNUMH im. O. M. Beketova [in Ukrainian].

Neanidis, K.C. (2019). Volatile capital flows and economic growth: The role of banking supervision. Journal of Financial Stability, 40, 77-93. https://doi.org/10.1016/j.jfs.2018.05.002

Nebava, M. I. (2017). Ekonomichna bezpeka pidpryiemstva: navchalnyi posibnyk [Economic security of the enterprise: a textbook]. Vinnytsia, Ukraine: VNTU [in Ukrainian].

Nikitina, A.V., Novikova, T.V., \& Khrystoforova, O.M. (2019). Structural and functional model of enterprise economic safety management system in the global financial space. Financial and Credit Activity: Problems of Theory and Practice, 3(30), 136-146. https://doi.org/10.18371/fcaptp.v3i30.179692

Osberg, L. (1997). Economic growth, income distribution and economic welfare in Canada 19751994. The North American Journal of Economics and Finance, 8(2), 153-166. https://doi.org/10.1016/S1062-9408(97)90005-X

Pająk, K., Kamińska, B., \& Kvilinskyi, O. (2016). Modern trends of financial sector development under the virtual regionalization conditions. Financial and Credit Activity: Problems of Theory and Practice, 2(21), 204-217. https://doi.org/10.18371/fcaptp.v2i21.91052

Savchenko, T., Basiurkina, N., Rodina, O., \& Kwilinski, A. (2019). Improvement of the assessment methods of product competitiveness of the specialized poultry enterprises. Management Theory and Studies for Rural Business and Infrastructure Development, 41(1), 43-61. https://doi.org/10.15544/mts.2019.05

Silva, W., Kimura, H., \& Sobreiro, V.A. (2017). An analysis of the literature on systemic financial risk: A survey. Journal of Financial Stability, 28, 91-114. https://doi.org/10.1016/j.jfs.2016.12.004 
Sobolev, V.M., \& Soboleva, M.V. (2015). Metodolohichni zasady doslidzhennia ekonomichnoi bezpeky v Ukraini u suchasnykh umovakh [methodological basis of research of economic security in ukraine in modern conditions]. Financial and Credit Activity: Problems of Theory and Practice, 2(19), 186-194. https://doi.org/10.18371/fcaptp.v2i19.57284 [in Ukrainian].

Tkachenko, V., Kwilinski, A., Klymchuk, M., \& Tkachenko, I. (2019a). The economicmathematical development of buildings construction model optimization on the basis of digital economy. Management Systems in Production Engineering, 27(2), 119-123. http://doi.org/10.1515/mspe-2019-0020

Tkachenko, V., Kwilinski, A., Korystin, O., Svyrydiuk, N., Tkachenko, I. (2019b). Assessment of information technologies influence on financial security of economy. Journal of Security and Sustainability, 8(3), 375-385. http://doi.org/10.9770/jssi.2019.8.3(7)

Tkachenko, V., Kwilinski, A., Tkachenko, I., \& Puzyrova, P. (2019c). Theoretical and methodical approaches to the definition of marketing risks management concept at industrial enterprises. Marketing and Management of Innovations, 2, 228-238. http://doi.org/10.21272/mmi.2019.2-20

Tkachenko, V., Kwilinski, A., Kaminska, B., Tkachenko, I., \& Puzyrova, P. (2019d). Development and effectiveness of financial potential management of enterprises in modern conditions. Financial and Credit Activity: Problems of Theory and Practice, 3(30), 85-94. https://doi.org/10.18371/fcaptp.v3i30.179513

Vishnevsky, V.P. \& Kwilinski A. (2019a). Monetarni mechanizmy stymuluvannia ekonomiky v rozvynenych krainach: analitychnyi oglad [Monetary mechanisms of an economy stimulation in developed countries: an analytical review]. Economy of Industry, 1(85), 30-50. http://doi.org/10.15407/econindustry2019.01.030 [in Ukrainian].

Vishnevsky, V.P. \& Kwilinski A. (2019b). Novitni trendy v monetarniy politytsi USA ta ii vplyv na ekonomichnyi rozvytok: analitychnyi oglad [Recent trends in US monetary policy and its influence on economic development: an analytical review]. Economy of Industry, 3(87), 125-142. https://doi.org/10.15407/econindustry2019.03.125 [in Ukrainian].

Williamson, O. (1975). Markets and Hierarchies: Analysis and Antitrust Implications. New York: Free Press. 